\title{
Improvement of IT Infrastructure Management by Using Configuration Management and Maturity Models: A Systematic Literature Review and a Critical Analysis
}

\author{
João P. SERRANO, Rúben F. PEREIRA
}

\author{
Instituto Universitário de Lisboa (ISCTE-IUL), Lisbon, Portugal, \\ joaoserrano.31@gmail.com (Corresponding author), rubenfspereira@gmail.com
}

\begin{abstract}
Background and purpose: This research aims to investigate which benefits one may expect using Maturity Models in Configuration Management (CM) domain. $\mathrm{CM}$ is a support process that helps organizations have better management of their infrastructure. Its importance, in the Information Technology (IT) domain, has increased in recent years, despite this process not being technologically new, and the fact that many organizations implement this process in a haphazard way, which results in it not producing the benefits that it should produce. With the intention of assessing and improving the organizations' IT processes practices and capabilities, MMs have been developed and implemented. However, the application of MM in the CM domain is yet to be explored.

Design/Methodology/Approach: Two Systematic Literature Reviews (SLRs) and a Critical Analysis were performed. In sum, 80 scientific articles of the most rated conferences and scientific journals were analyzed and conclusions were drawn.

Results: This research concludes that despite the CM process being badly implemented, using a MM this process could decrease operational costs and increase the quality management of the infrastructure.

Conclusion: However, no MM has been developed so far for the CM process practices. This MM would be a viable support tool for the IT organizations providers since this would help organizations have a mature CM process and better control of their IT infrastructure. Therefore, the existence of a MM for the CM domain would be a welcome advancement that should be developed in the future.
\end{abstract}

Keywords: Configuration Management Process, Maturity Models, IT Services Providers, Systematic Literature Review

\section{Introduction}

Nowadays, it is imperative that IT organizations follow consumer tendencies and wills, with maximum effectiveness and efficiency (Asif, 2016). In fact, IT infrastructures are becoming more organizationally centralized, as these infrastructures are becoming more important, with or- ganizations being more IT-dependent. This environment increases the importance and essentiality of IT organizations' business development and organization strategies (Ertürk \& Vurgun, 2015). As a result of the considerable number of internal dependencies and relations among the systems and services provided by an organization (Vanbrabant \& Joosen, 2013), it is making IT infrastructures

Received: October 29, 2019; revised: January 24, 2020; accepted: February 8, 2020 
more complex and wider. Because of that reason and the increase of IT systems' heterogeneity, the weight of IT infrastructure management is increasing in our society, causing an increase in administration costs (Giese et al. 2010). This crucial environment, where IT performance impacts organization revenue, if not efficiently managed, can "lead to errors and subsequently to failures", determining the difference between profit and loss (Baiôco et al. 2009; Vanbrabant \& Joosen, 2013).

In line with the substantial increase of the IT value in organizations is the evolution that it has provided. In an environment where success depends on clients, it is critical to address customer demands and explore new business opportunities. These conditions have allowed significant advances in IT, granting an evolution in IT services, and the satisfaction of internal and external organizational customer requirements (Johnson et al. 2007). The rising number of service providers allowed the increase of their share in the IT market (Levstek et al., 2018). Subsequently, they have naturally become important to the world's economy (Hashmi et al. 2010).

The services are developed and implemented on a subjacent IT infrastructure, which may consist of thousands of components, from software to hardware, which requires management in conformity with organizational objectives (Hashmi et al., 2010; Madduri et al., 2007). In this complex universe, where there is a competitive and rigorous market that gives rise to constant technological evolution (Baiôco et al., 2009), not only is the management of infrastructure changes necessary, but also an awareness of the risk and impact that they can impose on the organization (Ali \& Kidd, 2013).

Therefore, the necessity to implement a process that would be essential to manage the whole IT infrastructure information has emerged (Madduri et al., 2007). Many solutions to support this kind of task were proposed in order to make a feasible "platform" that allowed the organization's collaborators to manage the infrastructure information and changes (Yang, 2010), which has led to the emergence in recent years of studies on the process of $\mathrm{CM}$ and its feasibility.

The importance of the CM process has been growing (Ali \& Kidd, 2015), providing clear and fundamental information to all "kinds of performers" in enterprises (Baiôco et al., 2009). In spite of CM being essential to organizations, it is often misunderstood and is not given the proper importance by strategic management (Ali \& Kidd, 2013; Shah et al. 2012). This process, if implemented in a careless and inaccurate way, can lead to equipment failures or even service disruptions, hence the increase in costs increase and the decrease in effectiveness in organizations (Choi \& Bae, 2001).

With the purpose of assessing organizational practices, organizations have been using MMs (Haes \& Grembergen, 2004; Patas et al. 2013), which in the IT industry has grown exponentially due to its importance. Organizations have applied these models not exclusively for evaluation, but also to "benchmark and to improve their process capabilities" (Proença, 2016).

This research aims to give further insights about the following research question:

- Would the CM domain benefit from the application of MM?

In order to review the $\mathrm{CM}$ process and the $\mathrm{MM}$ domain over the years and draw conclusions about the possibility of the conjunction of both domains, the Systematical Literature Review (SLR) methodology was adopted.

This research is structured as follows. The next chapter introduces the methodology used to obtain the final articles and a brief introduction is given to the $\mathrm{CM}$ and $\mathrm{MM}$ domains. Chapter 3 includes a discussion about the necessity to create a MM for the CM process. Finally, in the last chapter, some conclusions of this research are presented.

\section{Methodology}

SLR is a type of literature review and an approach to conducting a rigorous literature review, with the view of collecting data and found evidence in order to draw conclusions about research investigations. The authors Okoli and Schabram (2010) define SLR as "a systematic, explicit and reproducible method for identifying, evaluating, and synthesizing the existing body of completed and recorded work produced by researchers, scholars, and practitioners". SLR can improve literature reviews by bringing transparency and rigours in numerous ways, with the support of several systematic methods (Mallett et al. 2012).

With the intention of meeting the goals attached to this investigation and with the requirement to explain the "context" and the main concepts of this research, two SLRs were conducted, with the support of the Concept Centric (CC) method. This research is based on the guidelines for conducting a SLR of the author Kitchenham (2004). The steps taken to conduct these reviews are visible in Figure 1.

In order to present the insights generated by the SLR methodology, this research adopted the $\mathrm{CC}$ guidelines of Jane Webster and Richard Watson (2002).

\subsection{Outlining Systematic Literature Review}

These SLRs not only have the objective of justifying why the creation of a MM for the CM process is a feasible solution, granting many benefits to the management of an organization, but also the contextualization of the concepts of CM and MM. In order to achieve these objectives two SLRs were individually conducted: for the CM process and $\mathrm{MM}$ domain. For each domain, the $\mathrm{CC}$ approach was adopted to "centralized" the principal concepts intrinsical- 
ly connected with each domain.

To obtain information about these two domains, five electronical repositories were selected: IEEE Online Library, SpringerLink, Elsevier, ACM and ResearchGate. The electronic repositories were the same for both approaches. However, two different keywords were used, for which an explanation lies in the following sections. Further, this review included only English and Portuguese articles and exclusively articles published on Journals or Scientific Magazines and Conferences Proceedings were accepted. Additionally, no date filter was used. Two search strings were used, one for each domain. Even though the keywords were established at this stage, with a view of research structuration it was decided to introduce them in the following sections.

The search process was the same for both domains. Initially a search was carried out with the selected keywords in each repository, without any filter. After that, four filters were created. Nevertheless, all the electronic libraries use different "search approaches", so a keyword adaptation for each repository was done.

The first filter applies the keywords from the article title, or the abstract or the author's keywords; In the second one, duplicated articles are removed; In the third filter, articles that are published in lower publications/journals rank are removed. For that reason, two websites, Scimago ${ }^{1}$ and Conference Ranks ${ }^{2}$, were used, which provide journals and conferences ranks, respectively. For conferences only A, B, A1, A2, B1 and B2 ranks of ERA and Qualis rankings were accepted. When an article was assessed by both rankings, Qualis prevailed. For journals, only Q1 and Q2 ranks were accepted. Finally, the last stage of filtration was realized by assessing articles' introductions and con- clusions. The inclusion criteria of this filter of each domain are explained in the next sub-sections.

\subsection{Conducting a Systematic Literature Review}

As previously mentioned, SLR was divided into two domains and the resulting articles needed to "proceed" through four filters. Both domains filtration process, by each online repository and each filter, are demonstrated in the following sub-sections.

The first filter had the purpose of separating the articles that are exclusively related to both domains of those which just made a reference to these concepts in the body of the article, by just selecting the ones that had the keywords in the title, abstract and author's keywords. These three article sections were chosen for being the main parts that summarise the article's content. With this filter it was possible to discard a substantial number of articles.

The second filter had the intention of eliminating the duplicated articles.

In the third filter, 1336 articles were ranked based on their publication, which was in total nearly 890 publications since various articles had the same publication (conference/journal). Consequently, 577 articles' introduction and conclusion were read and evaluated by each domain inclusion criteria, which resulted in 80 final articles. The final articles divided by each publication rank are shown in Table 1. Articles from conference proceedings were the main contributor, making up $60 \%$ of the resulting articles from conferences. It is important to mention that approximately $28 \%$ of the final articles are from journals with a Q1 rank.

\begin{tabular}{|c|c|c|}
\hline $\begin{array}{c}\text { Outlining Systematic } \\
\text { Literature Review }\end{array}$ & $\begin{array}{c}\text { Conducting Systematic } \\
\text { Literature Review }\end{array}$ & Reporting the Review \\
\hline $\begin{array}{l}\text { - Identification of the need for a } \\
\text { review. } \\
\text { - Necessity to have a better } \\
\text { management of the IT } \\
\text { Infrastructure. } \\
\text { - Objective of the review. } \\
\text { - Gather information about both } \\
\text { domains and their connection. } \\
\text { - Review protocol. } \\
\text { - Search string, filters, repositories } \\
\text { and inclusion criteria. }\end{array}$ & $\begin{array}{l}\text { - Applying filters and get final } \\
\text { articles. } \\
\text { - } 80 \text { articles. } \\
\text { - Perform Data extraction. } \\
\text { - Information extraction from } \\
\text { selected articles of each } \\
\text { domain. }\end{array}$ & $\begin{array}{l}\text { - Summarize the data extracted } \\
\text { obtained of each domain. } \\
\text { - Reporting the findings. } \\
\text { - Conclusions of CM and } \mathrm{MM} \\
\text { domains. }\end{array}$ \\
\hline
\end{tabular}

Figure 1: Systematic Literature Review Stages (Adapted from Kitchenham (2004) guidelines)

1 Scimago website: https://www.scimagojr.com

2 Conference Ranks website: http://www.conferenceranks.com/\#data 
Table 1: Final Articles by Publication Rank of Both Domains

\begin{tabular}{|c|c|c|}
\hline & Conference rank & Total \\
\hline \multirow{2}{*}{$\underset{\underline{a}}{\overleftrightarrow{c}}$} & $\mathrm{~A}$ & 5 \\
\hline & B & 2 \\
\hline \multirow{4}{*}{ 先 } & A1 & 8 \\
\hline & $\mathrm{A} 2$ & 10 \\
\hline & B1 & 13 \\
\hline & B2 & 10 \\
\hline & & 48 \\
\hline
\end{tabular}

\begin{tabular}{|c|c|}
\hline Journal rank & Total \\
\hline Q1 & 22 \\
\hline Q2 & 10 \\
\hline & 32 \\
\hline
\end{tabular}

\subsubsection{Systematic Literature Review of Configuration Management}

The CM domain search had the purpose of finding its main concepts in "generic" domains, but with a focus on the IT services field. Keywords (listed below) were used in all repositories with operators AND and OR, being "Configuration Management" the main keyword. The flow of the entire filtration process can be seen in Figure 2.

\section{"Configuration Management"}

AND

("Maturity Model” OR "Frameworks" OR "Good Management Practices" OR "International Standards" OR "Main Concepts" OR "Barriers" OR "IT Service

\section{Management"}

Since ResearchGate is a social network for professionals where it is possible to publish articles, which are accessible to the entire community, there may be articles from other online libraries. In fact, on ResearchGate four articles from IEEE repository were found, two from ACM and two from SpringerLink that were not found in their own repository with the same keywords, which shows the differences between each repository search approach.

In the last filter, where an evaluation of the article's introduction and conclusion is realized as mentioned previously, the following inclusion criteria were followed:

- $\quad$ articles, exclusively about CM theme, in any domain, were accepted;

- $\quad$ articles about CM benefits and the problems/risks of a bad process implementation were accepted;

- $\quad$ articles about CM process characteristics were accepted.

Articles that did not meet at least one of these "requirements" were rejected. The comparison number between conference papers and journal articles that fulfil all requisites, is visible in Table 2.

Table 2: Conference Papers vs Journal Articles of Configuration Management Domain

\begin{tabular}{|c|c|}
\cline { 2 - 2 } \multicolumn{1}{c|}{} & Total \\
\hline Conference Papers & 18 \\
\hline Scientific Magazines/Journals & 12 \\
\hline \multicolumn{2}{c|}{} \\
\cline { 2 - 2 }
\end{tabular}

Table 3: Filtration Process of Configuration Management Domain

\begin{tabular}{|c|c|c|c|c|c|}
\cline { 2 - 6 } \multicolumn{1}{c|}{} & No Filter & 1st Filter & 2nd Filter & 3rd Filter & 4th Filter \\
\hline IEEE & 3022 & 86 & 81 & 38 & 5 \\
\hline ACM & 2792 & 118 & 67 & 35 & 3 \\
\hline SpringerLink & 3249 & 78 & 78 & 24 & 1 \\
\hline ScienceDirect & 1755 & 30 & 30 & 19 & 1 \\
\hline ResearchGate & 199 & 199 & 140 & 52 & 20 \\
\hline Total & 11017 & 511 & 396 & 169 & 30 \\
\hline
\end{tabular}




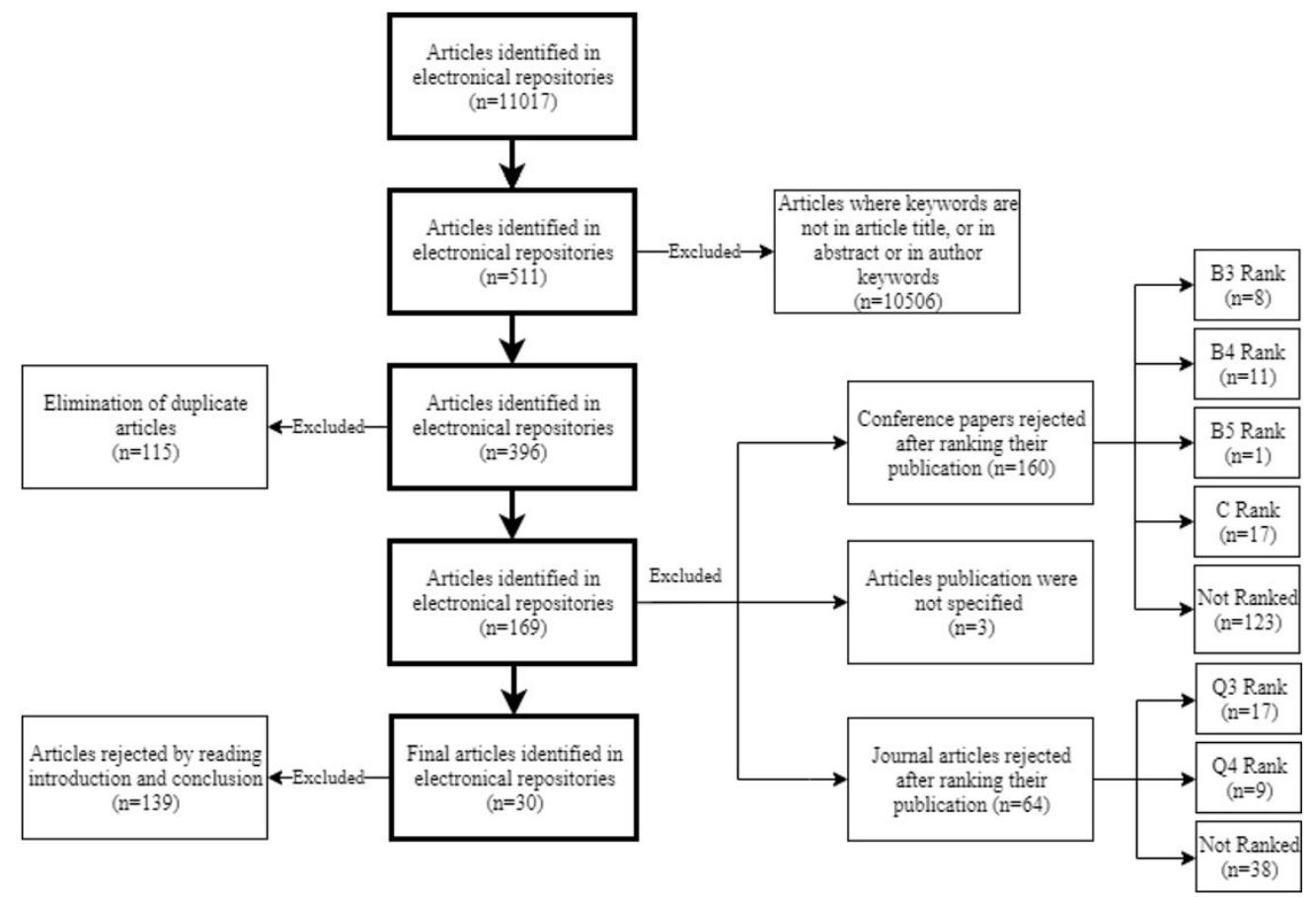

Figure 2: Flow of all Filtration Process of Configuration Management Domain

In sum, it is possible to visualize the filtration process for this domain by each filter and by each repository, in Table 3.

\subsubsection{Systematic Literature Review of Maturity Model}

Following the generic search approach discussed initially in this chapter, on MM domain the focus was not just in the IT domain, but as also in other domains, with a view to finding general benefits and difficulties in this domain. Specific keywords (listed below) for this search were used in all repositories with operators AND and OR, with the "Maturity Model" concept being the main keyword.

\section{"Maturity Model" AND}

("IT Frameworks" OR "Best practices" OR "Main Concepts" OR "Benefits" OR

"IT Management" OR "Risks")
In the same way, as in the CM domain research, the articles found in ResearchGate's repository were added manually and the first filter was not applied in this case. In ResearchGate four articles from SpringerLink and one from IEEE were found, which were not found in their own repositories with the same keywords. Figure 3 shows all the filtration process in MM domain research.

On the last filter, the inclusion criteria were:

- $\quad$ articles about MM in any domain were accepted;

- articles about MM general characteristics were accepted;

- articles about MM benefits of any domain and MM general problems were accepted.

Articles that did not meet at least one of these "requirements" were rejected.

Table 4 shows a comparison between the number of journal articles and conference papers of the filtration result.

With the same view of the CM SLR, in order to have a higher understanding and comprehension of the MM domain filtration process was constructed the Table 5.

Table 4: Conference Papers vs Journal Articles of Maturity Model Domain

\begin{tabular}{|c|c|}
\cline { 2 - 2 } \multicolumn{1}{c|}{} & Total \\
\hline Conference Papers & 30 \\
\hline Scientific articles (Scientific Magazines/Journals) & 20 \\
\hline & 50 \\
\hline
\end{tabular}




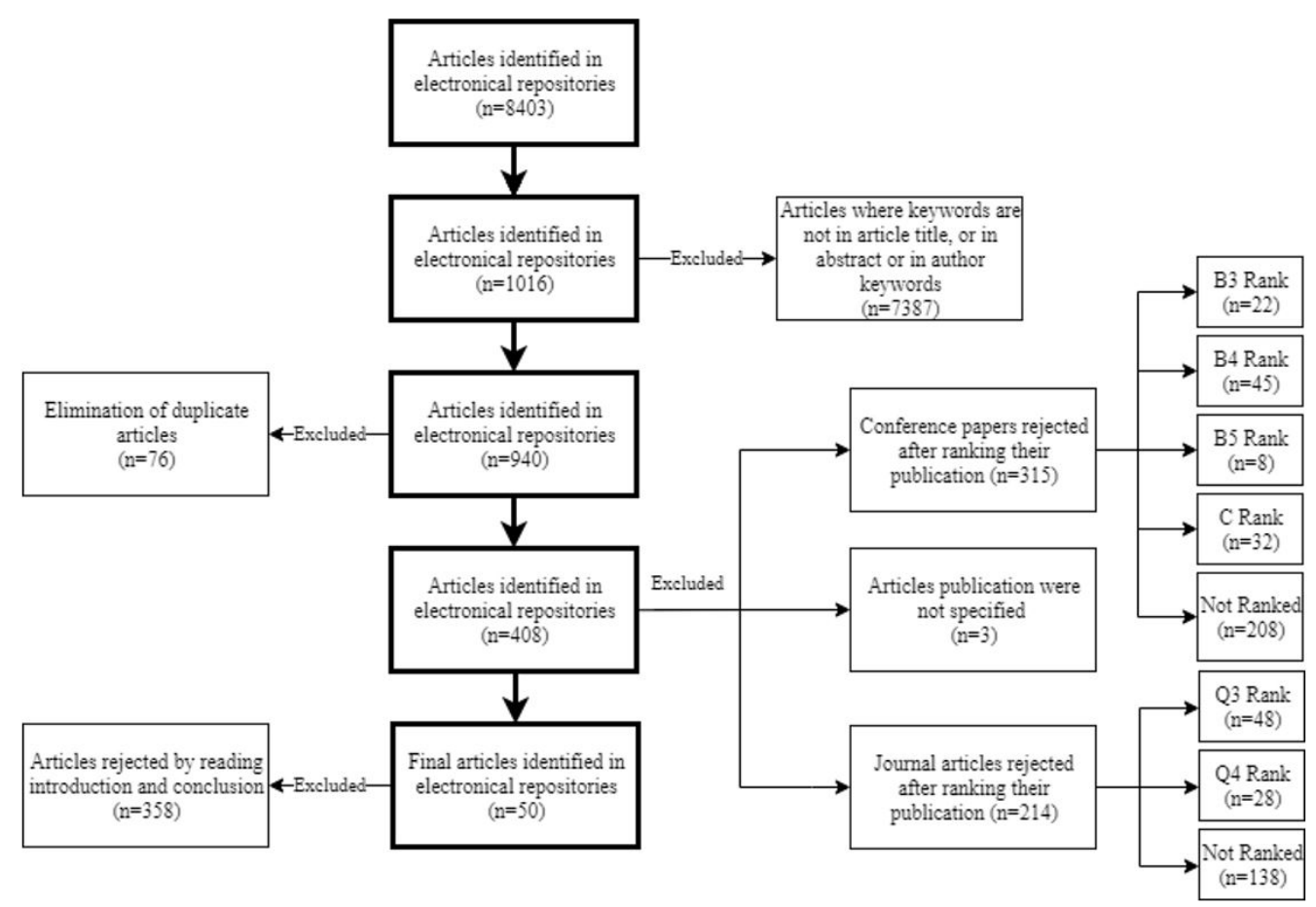

Figure 3: Flow of all Filtration Process of Maturity Model Domain

Table 5: Filtration Process of Maturity Model Domain

\begin{tabular}{|c|c|c|c|c|c|}
\cline { 2 - 6 } \multicolumn{1}{c|}{} & No Filter & 1st Filter & 2nd Filter & 3rd Filter & 4th Filter \\
\hline IEEE & 2729 & 232 & 231 & 94 & 5 \\
\hline ACM & 174 & 54 & 54 & 18 & 6 \\
\hline SpringerLink & 2529 & 126 & 126 & 52 & 12 \\
\hline ScienceDirect & 2560 & 193 & 193 & 122 & 11 \\
\hline ResearchGate & 411 & 411 & 335 & 122 & 16 \\
\hline Total & 8403 & 1016 & 940 & 408 & 50 \\
\hline
\end{tabular}

\section{Configuration Management}

Making important decisions is a critical and decisive point in organizations. These days, ITs are becoming fundamental tools for this type of tasks, allowing organizations to achieve their structural and strategic objectives (Na-Lampang \& Vatanawood, 2016), enhancing their indispensability in organizations. Modifications to IT services and IT infrastructure configurations must be managed with extreme caution in order to prevent service interruptions (Johnson et al., 2007). CM is an important support process in the management of any infrastructure that permits an efficient and effective control, promoting critical and important information in any organization division (Baiôco \& Garcia, 2010), attending to these configurations changes in a secure way.

Despite the fact that the importance of CM has been in- creasing in recent years, this process is not technologically new. In the 1950s, during the period of the "arms race", in order to enhance the production pipeline to reduce the missiles manufacturing time of missiles, the US Department of Defense established CM to control product specifications and deal with alterations during the product life cycle, as well as to create an accessible and conformed documentation. Therefore, with the purpose of having better control and to regulate how projects should be managed, CM standards were developed. CM expanded beyond its industries roots, since "society" started to become aware of the fact that the majority of businesses are comprised of systems with high complexity which suffer constant changes due to their dynamic environment (Ali \& Kidd, 2014; Burgess et al. 2005).

CM recognition has been growing (Ali \& Kidd, 2015), despite not being a new concept (Ali \& Kidd, 2014). It is 
a set of actions whose aim is the management of services and product configurations (Aleksic et al. 2010), and to enhance the service provision quality (Hashmi et al., 2010). This process has a big responsibility not just in managing IT assets and its configurations (Lahtela \& Jantti, 2010), but also in providing crucial and accurate information about these "components" to organization operators, such as organization collaborators or even to other service management processes (Baiôco et al., 2009). This conceded information permits an image of the constitution of the IT infrastructure, allowing them to identify any change that might affect the systems or the infrastructure, assuring the collaborators of fundamental information in decisions that may be taken (Yang, 2010). In Table 6, the main concepts associated with CM are shown: Configuration, Configuration Item and CM Database.

As previously mentioned, CM provides an infrastructure or service model through "identification, controlling, maintaining and verification of existing Configuration Items versions" (Baiôco et al., 2009). CM is defined as having several sub-processes: Configuration Item Identification, Configuration Item Control, Configuration Item Verification and Audit, and finally Configuration Item Status Accounting and Reporting (Madduri et al., 2007). CM sub-processes definitions can be seen in Table 7 .

Despite the fact that the influence ofCM is expanding in the IT Services context (Na-Lampang \& Vatanawood, 2016), in this state-of-the-art research, this process was also found in other IT scenarios, being closely related to Engineering Software, the CM concept having been identified in various contexts, such as project management, defined as Project Configuration Management (PCM), and in software development, designated as Software Configuration Management (SCM), for which a brief explanation is given in Table 8 .

Table 6: Main Configuration Management Concepts Found

\begin{tabular}{|c|c|c|}
\hline Concepts & Description & References \\
\hline Configuration & $\begin{array}{l}\text { A configuration is frequently referred to as all of the } \\
\text { connection of all computer system parts, or a set of } \\
\text { items that form a product. }\end{array}$ & $\begin{array}{l}\text { (Aleksic et al., 2010; Calhau \& de } \\
\text { Almeida Falbo, 2012; Choi \& Bae, } \\
\text { 2001; Whyte et al. 2016) }\end{array}$ \\
\hline Configuration Item & $\begin{array}{l}\text { When a configuration product item is under manage- } \\
\text { ment is called Configuration Item. Configuration Item } \\
\text { is defined as "an infrastructure component or an item" } \\
\text { that have value to the organization, and are vulnerable } \\
\text { to change, with the necessity to be tracked throughout } \\
\text { its lifecycle. These items may have different sizes and } \\
\text { might be services, incidents, hardware components or } \\
\text { even software packages. In several cases, it may well } \\
\text { be persons. }\end{array}$ & $\begin{array}{l}\text { (Aleksic et al., 2010; Baiôco et al., } \\
\text { 2009; Calhau \& de Almeida Falbo, } \\
\text { 2012; Giese et al., 2010; Johnson et al., } \\
\text { 2007; Lahtela \& Jantti, 2010; Na-Lam- } \\
\text { pang \& Vatanawood, 2016; Pantoni et } \\
\text { al. 2007; Ward et al. 2007; Whyte et al., } \\
\text { 2016) }\end{array}$ \\
\hline CM Database & $\begin{array}{l}\text { Configuration Items and their relations are saved in } \\
\text { a database known as CM Database. CM Database is } \\
\text { an IT conceptual model with a predominant role in } \\
\text { efficient IT service management. This database is an } \\
\text { auxiliary valuable tool to perform decisions provid- } \\
\text { ing Configuration Items dependencies and links in } \\
\text { the business, showing promptly the IT infrastructure } \\
\text { details, enhancing the quality and efficiency of IT } \\
\text { systems. }\end{array}$ & $\begin{array}{l}\text { (Baiôco et al., 2009; Giese et al., 2010; } \\
\text { Johnson et al., 2007; Lahtela \& Jantti, } \\
\text { 2010; Madduri et al., 2007; Na-Lam- } \\
\text { pang \& Vatanawood, 2016; Ward et al., } \\
\text { 2007; Yang, 2010) }\end{array}$ \\
\hline
\end{tabular}


Table 7: Configuration Management Sub-Processes

\begin{tabular}{|l|l|l|}
\hline Sub-processes & Description & References \\
\hline $\begin{array}{l}\text { Configuration Item Identi- } \\
\text { fication }\end{array}$ & $\begin{array}{l}\text { Configuration Item identification is considered as an essential } \\
\text { process to the system efficiency, where the identification of the } \\
\text { items that will be under tracking will be realized. }\end{array}$ & $\begin{array}{l}\text { (Aleksic et al., 2010; Ali \& } \\
\text { Kidd, 2013, 2015; Baiô- } \\
\text { co et al., 2009; Calhau \& } \\
\text { de Almeida Falbo, 2012; }\end{array}$ \\
\cline { 1 - 2 } Configuration Item Control & $\begin{array}{l}\text { Configuration Item control sub-process permits only authorized } \\
\text { changes realized to Configuration Items. } \\
\text { al., 2007; Na-Lampang \& }\end{array}$ \\
\cline { 1 - 2 } $\begin{array}{l}\text { Configuration Item Verifica- } \\
\text { tion and Audit }\end{array}$ & $\begin{array}{l}\text { This sub-process proceeds to the verification of Configuration } \\
\text { Item status and integrity, checking if they are in conformity with } \\
\text { organization policies and standards. }\end{array}$ & $\begin{array}{l}\text { et al., 2007; Whyte et al., } \\
\text { 2016) }\end{array}$ \\
\cline { 1 - 2 } $\begin{array}{l}\text { Configuration Item status } \\
\text { accounting and reporting }\end{array}$ & $\begin{array}{l}\text { Configuration Item status accounting sub-process, realizes infor- } \\
\text { mation and historic report of the Configuration Items, guarantee- } \\
\text { ing the availability of this data to the organization executors. }\end{array}$ & \\
\hline
\end{tabular}

Table 8: Configuration Management IT Contexts Found

\begin{tabular}{|c|c|c|}
\hline Contexts & Description & References \\
\hline SCM & $\begin{array}{l}\text { SCM gained particular recognition when Capability Maturity Model was } \\
\text { developed, being this process established as a discipline of software devel- } \\
\text { opment support in teams, which its main function is the accompaniment of } \\
\text { the software products development. SCM is a set of principles and practices } \\
\text { that are crucial to the software development support, directing the product } \\
\text { changes, like programming code (source code), following the software de- } \\
\text { sign documentation. SCM comes to support brief software development in } \\
\text { a manner that can increase the quality and decrease the development time. }\end{array}$ & $\begin{array}{l}\text { (Buchmann et al. 2013; Choi } \\
\& \text { Bae, 2001; Conradi \& } \\
\text { Westfechtel, 1998; Fahmy, } \\
\text { Deraman, \& Yahaya, 2018; } \\
\text { Pala Er \& Erbaş, 2010; Pan- } \\
\text { toni et al., 2007; Park, Kim, } \\
\& \text { Lee, 2007; Tellioglu, } \\
\text { 1996; Wandel et al. 2013; } \\
\text { Whyte et al., 2016) }\end{array}$ \\
\hline PCM & $\begin{array}{l}\text { Since information asset in a project has become a project deliverable, PCM } \\
\text { importance has gained some relevance. It is referred to as PCM when is } \\
\text { necessary bigger control documentation and deliverable, resulting in bet- } \\
\text { ter monitoring for project managers in the product lifecycle, that praise the } \\
\text { PCM as a significant factor in project management. }\end{array}$ & $\begin{array}{l}\text { (Fowler, 1996; Pantoni et } \\
\text { al., 2007; Whyte et al., 2016) }\end{array}$ \\
\hline
\end{tabular}

\section{Maturity Models}

As previously mentioned, the technological evolution rendered organizations more IT-dependent, motivating them to improve IT's control and security (Rao \& Jamieson, 2003). IT Organizations are growing in a complex way, having the requirement to evaluate their present situation, in order to, in a profitable manner, achieve their strategic objectives and project their future ( Reis et al. 2017).

Managing IT practices is crucial to conducting the growing IT business value (Curley et al., 2008). Certifying the effectiveness and efficiency of these practices is an IT strategic management role (Hamel et al. 2013), whose main goal is to "continually improve IT performance with regard to its economic efficiency" (Becker et al. 2009). Hence, enterprises need to evaluate their actual position to in a strategic way, plan their proper investments (Schäffer et al., 2018). However, traditional measures were inadequate and consequently, a new "assessing methodology" emerged known as MM (Karni et al. 2013).
MMs are gradually becoming more important to organizations and any domain (Hammers et al., 2017). This concept began to be recognized 40 years ago (J. V. Carvalho et al., 2017). These models started to emerge when quality management practices were successfully implemented in manufacturing processes (Kwak et al. 2015).

Crosby was one of the pioneers, when in 1979 the structure that is subjacent to the maturity framework was created (Rao \& Jamieson, 2003), conceiving a Quality Management Maturity Grid (Nord et al. 2016). His creation contributed significantly to the development of the quality maturity concept (Wang et al. 2016). At the end of the 1980s, the US Government with the intention of evaluating the capabilities of software companies, proposed to Watts Humphrey, to the Software Engineering Institute and to Miter Corporation to solve this task. The result of this task was the well-known Capability Maturity Model (CMM) (Humphrey, 1988). The MM's notoriety grew with the creation of this model (Mettler \& Rohner, 2009), which provoked a strong adherence by organizations of 
all domains and the attention of the research community (Achi et al., 2016), and diverse models in different domains were created, in construction (Jia et al., 2013), or in project management (Brookes et al. 2014), or even in the agriculture sector (L. Reis et al., 2018). MM is intrinsically associated with three concepts. Their description can be visualized in Table 9.

The author M. Fairchild (2004) defines the MM as "a method for judging whether processes used, and the way they are used, are characteristic of a mature organization". MMs can be seen as a tool (Curry et al., 2013), used to evaluate the as-is state of an organization (Antunes et al. 2014) and to enhance the organization's capabilities (Proença et al., 2013). The main idea of the MM concept is, in a succinct manner, to assess the activities behaviour of an organization at a certain number of maturity levels et al. 2009). This assessment is "constructed" by a comparison between a set of criteria and characteristics, provided by a MM, and the organization activities behaviour, shown in a gradual scale (Lã, 2011), assigning a state or a maturity level to an organization capability or a capability combination (Desharnais \& April, 2010).

MM defines an improvement path for the development of these organizational capabilities (Carvalho et al. 2018), displaying the best procedures to obtain a higher level of maturity (Proença \& Borbinha, 2018). Although it is not an indispensable requisite to obtain the MM maximum level (Hamel et al., 2013) since each organization has its optimum level, which is defined as "the level that delivers the organization's strategic objectives most effectively and efficiently", which does not correspond to the scale's highest level (Introna et al. 2014). The improvement/implementation path can distinguish the type of MM. The two types of paths are characterized in Table 10.

One of the MM's main roles is to identify an organization's weaknesses and strengths (Lahrmann et al., 2010) in order to subsequently be able to create a capability improvement path and create a strategic plan for the future (Frick et al., 2013). In the literature, three specific purposes for the use of MMs were found. The description of these three purposes is presented in Table 11.

Table 9: Maturity Model Concepts

\begin{tabular}{|l|l|l|}
\hline Concepts & Description & References \\
\hline Maturity & $\begin{array}{l}\text { Maturity concept has been described as a "state in which } \\
\text { an organization is perfectly able to achieve the goals it sets } \\
\text { itself". This concept is recognized as a measure to assess } \\
\text { how-well are the organization capabilities. The maturity } \\
\text { "component" it may be an object, a system or a person. }\end{array}$ & $\begin{array}{l}\text { (Antunes et al., 2014; Brooks et al. 2015; Clev- } \\
\text { en et al. 2014; Hammers et al., 2017; Introna et } \\
\text { al., 2014; Karni et al., 2013; Mayer \& Fagun- } \\
\text { des, 2009; Mettler \& Rohner, 2009; Proença \& } \\
\text { Borbinha, 2018; Proença et al., 2017, 2018; T. } \\
\text { L. Reis et al., 2017; Vezzetti et al. 2014) }\end{array}$ \\
\hline Capability & $\begin{array}{l}\text { A Capability is characterized as the ability of an organiza- } \\
\text { tion to produce value. Organizations use their capabilities } \\
\text { strategically to improve their "abilities" to another level of } \\
\text { efficient and effective. }\end{array}$ & $\begin{array}{l}\text { (Bezerra et al. 2014; Curley et al., 2008; Hauck } \\
\text { \& Wangenheim, 2011; Karni et al., 2013; Picard } \\
\text { et al., 2015; T. L. Reis et al., 2017; Wendler, } \\
\text { 2012) }\end{array}$ \\
\hline $\begin{array}{l}\text { Maturity } \\
\text { Levels }\end{array}$ & $\begin{array}{l}\text { Maturity Levels or stages are a sequential path, not just } \\
\text { to give an improvement path to organization, but as well } \\
\text { as "situate" organization capabilities in a hierarchal level. } \\
\text { Maturity Levels are often five, and each one has its proce- } \\
\text { dures to implement in order to achieve that level. }\end{array}$ & $\begin{array}{l}\text { Carvalho et al., 2018; Cleven et al., 2014; Frick } \\
\text { et al., 2013; Introna et al., 2014; Lahrmann et } \\
\text { 2016; Proença \& Borbinha, 2018; Serenko et al. } \\
\text { 2016; Vezzetti et al., 2014) }\end{array}$ \\
\hline
\end{tabular}

Table 10: Types of Improvement/Implementation Path

\begin{tabular}{|c|c|c|}
\hline Paths & Description & References \\
\hline Staged & $\begin{array}{l}\text { The staged model helps an organization to improve its capabilities "as a whole". } \\
\text { To achieve a certain maturity level is required that the organization capabilities } \\
\text { are compliance with the characteristics of that level. This model help organiza- } \\
\text { tions to characterize the "overall state of the organization's capabilities". }\end{array}$ & \multirow{2}{*}{$\begin{array}{l}\text { (Antunes et al., 2014; Cle- } \\
\text { ven et al., 2014; Finnerty } \\
\text { et al. 2017; Karni et al., } \\
\text { 2013; Kayaga et al. 2013; } \\
\text { Lahrmann et al., 2010; } \\
\text { Mayer \& Fagundes, 2009; } \\
\text { Picard et al., 2015) }\end{array}$} \\
\hline Continuous & $\begin{array}{l}\text { In continuous path is the description of the procedures to improve/evaluate in- } \\
\text { dividually each capability of a domain to improve. Each capability can be at } \\
\text { different maturity level. This helps the organization to develop and characterize } \\
\text { the state of their individual capabilities and abilities. }\end{array}$ & \\
\hline
\end{tabular}




\begin{tabular}{|l|l|l|}
\hline Purposes & Description & References \\
\hline Descriptive & $\begin{array}{l}\text { MM can be used for an as-is situation of an organization, } \\
\text { easing a basic assessment of the organization's capabilities. In } \\
\text { descriptive purpose, MM is used as a "diagnostic tool". }\end{array}$ & $\begin{array}{l}\text { (Cleven et al., 2014; Finnerty et al., 2017; } \\
\text { Kayaga et al., 2013; Pã, 2011; T. L. Reis et } \\
\text { al., 2017; Röglinger et al. 2012; Röglinger } \\
\text { et al., 2018; Serenko et al., 2016) }\end{array}$ \\
\hline Prescriptive & $\begin{array}{l}\text { MM has a prescriptive purpose when gives an improvement } \\
\text { path to higher maturity level, providing guidelines and mea- } \\
\text { sures to an organization. }\end{array}$ & $\begin{array}{l}\text { Comparative purpose permits an organization to benchmark its } \\
\text { capabilities in externally and internally way, using a large num- } \\
\text { ber of historical data from another organization's assessments. }\end{array}$ \\
\hline
\end{tabular}

\section{Discussion}

As previously mentioned, CM is considered a process with the focus on quality. This process has great benefits, in terms of the identification of changes and the responsibility identification of those who performed them, maintaining the service's quality and integrity (Aleksic et al., 2010). Organizations in the service industry undergo changes frequently, and it is required to have a process that not only controls those changes but also maintains the IT infrastructure control and integrity in order to enhance the service's development and provision.

The CM process, at a developmental level, can be an essential tool in project delivery strategy because it reduces development time and minimizes risk or errors (Ali \& Kidd, 2014), which allows a substantial increase in the final product quality (Fowler, 1996). This process can be a core support tool of organization operationality by diminishing the delays in development and operations (Ali \& Kidd, 2013), not only that, but many of the enterprises implement this process to help in ensuring that the infrastructure is in conformity with the legislation and policies of its environment (Baiôco et al., 2009).

With all the literature review, it can be affirmed that the CM process can "produce" several benefits to an organization. This process intends to reduce the number of quality and conformity problems providing important information and also seeks to increase the capabilities and resources of the organization and reduce the risks. The CM process, being properly implemented and monitored, can "deliver" transparency, integrity and a bigger control to enterprises, increasing the quality of provision service's and client's satisfaction. However, it seems, by observing the number of papers in higher quality journals/conference's proceedings in the CM domain, that has not been given proper importance to this discipline. Moreover, it is defended that this process has not been taken into account by strategic management (Ali \& Kidd, 2013).

A bad or inexistent implementation of this process might bring problems such as service failures and defi- ciencies in performance (Hashmi et al., 2010), leading to an increase in operational costs as well as a decrease in effectiveness, thus leading to the reduction of quality (Choi \& Bae, 2001).

It is clear to note that, by comparing the benefits and the losses of a "bad or inexistent implementation" of the $\mathrm{CM}$ process and observing the research carried out in this domain, it is important that an organization have a proper implementation of the CM process and an improvement path plan.

In immature organizations, their processes are improvised and implemented in an ad-hoc manner, being difficult to take benefits from these processes. In this sort of organizations, where there is no process improvement plan, it may be a problem to achieve quality products. At the same time, in mature organizations where their processes are constantly updated, these enterprises can obtain quality products and exert more control over their projects and infrastructures (T. L. Reis et al., 2017).

MMs can help immature organizations become more robust and sustainable. These tools support organizations by assessing their process's current state and by defining an improvement path (Achi et al., 2016). This kind of assessment tools assists an organization in adapting to their environment and being more agile (Mettler \& Rohner, 2009), helping to find weak and strong "spots" and improving an organization's process quality (Achi et al., 2016). They will ensure low costs and the process's execution in lower time (Hamel et al., 2013).

According to the literature review, MMs are being developed in a wide scope of domains. In the IT domain, these tools contributed to the creation of best practices (Proença et al., 2013), helping the management in IT organizations (Curry et al., 2013). IT management practices are critical to IT business (Curley et al., 2008), so it is becoming necessary to have these practices at their maximum maturity level, depending on the organizations' objectives.

It is believed that the use of best-practices following standards and frameworks in the IT Service domain can bring many benefits to the organization's performance 
(Knahl, Bayro-Corrochano, \& Hancock, 2013). Several researchers have created MMs to help IT organizations implement important frameworks in their infrastructure, by helping them have a robust and easy control of the overall processes (Pereira \& Mira, 2010). In a practical way, some studies, with the realization of questionnaires to organizations that use best practices of frameworks like Capability Maturity Model Integration (CMMI) and Information Technology Infrastructure Library (ITIL), conclude that as processes' maturity levels grows, more benefits and fewer issues organizations will have, such as a positive impact on business performance, an increase in organization profitability and competitive leverage (Marrone \& Kolbe, 2010, 2011; Salman, Daim, Raffo, \& Dabic, 2018). In another study, the creation of MM for Incident Management process by following several frameworks has received good feedback from experts in the domain (Pereira et al. 2018), which seems that the utilization of frameworks for the creation of a MM could be a preference of IT organizations.

Even though MMs can bring many benefits, the improvement process is slow and it can take years to achieve a superior maturity level and to realize the benefits (Jiang et al. 2004).

Considering the losses that an organization can have by not giving importance to the $\mathrm{CM}$ process and the requirement to enhance this process by creating a strategic improvement plan, $\mathrm{MM}$ is a viable solution. By observing the benefits and objectives of both domains (CM and $\mathrm{MMs}$ ) it can be concluded that MM domain complements the $\mathrm{CM}$ process by assessing its current state and supporting it through an improvement path, rendering it a robust and mature process. On that premise, the creation of a MM for $\mathrm{CM}$ based on frameworks can be an essential tool for an organization, generating many benefits and mitigating the problems of an immature CM process.

Eventually, this research carried out a search for MMs that would address the CM process or other IT processes that would help to justify the necessity of creating this tool, and two MMs were found (Table 12).

To fulfil the gap of the inexistence of roadmaps that elucidates an organization about their CM process's maturity level, the authors Niknam, Bonnal and Ovtcharova (2013) have created a Configuration Management Maturity Model (CMMM) in the PLM domain. Their MM intends to evaluate the maturity of the CM process in scientific facilities to help them find their own gaps and improve this process. The authors of this model, with state-of-theart analysis and a study of the current MMs and standards, extracted the critical activities and dimensions of the CM. Subsequently, the authors developed four maturity levels.

In other research, with the requirement of having medical devices conformed with some directives and with the necessity the companies of medical devices produce files of histories with the software components used in the development of these devices, Caffery and Coleman (2007) have developed a MM for the medical device industry. The authors compared the regulations of medical device regulations and the best practices of the CM process domain of the CMMI model. MM is composed of five maturity levels.

These are the MMs created by the scientific research community that are most related to this research scope. Despite the fact that there are already two MMs for the CM, they do not have the scope on IT Services, where there is a domain that is constantly evolving, and its importance is growing. Considering there was no $\mathrm{MM}$ for $\mathrm{CM}$ process found that solves the problems that every service provider faces every day, the creation of this model can be a contribution to the scientific community, by helping to "add value" to the CM process of the IT providers. This model can support IT organizations by evaluating the CM process and planning an improvement path, which can converge to profit and better control their IT infrastructure.

For better comprehension of the results of this research, a summary is presented in Table 13.

Table 12: MMs Found in the Literature

\begin{tabular}{|l|l|l|l|l|l|}
\hline \multicolumn{1}{|c|}{ Articles } & \multicolumn{1}{|c|}{ Scope } & \multicolumn{1}{|c|}{ Area } & $\begin{array}{l}\text { Methodology } \\
\text { adopted }\end{array}$ & \multicolumn{1}{c|}{ Based on } & \multicolumn{1}{c|}{$\begin{array}{l}\text { Maturity } \\
\text { Levels }\end{array}$} \\
\hline $\begin{array}{l}\text { (Caffery \& } \\
\text { Coleman, } \\
\text { 2007) }\end{array}$ & Software & $\begin{array}{l}\text { Medical de- } \\
\text { vices indus- } \\
\text { try }\end{array}$ & Ad-Hoc & CMMI & 5 \\
\hline $\begin{array}{l}\text { (Niknam, } \\
\text { Bonnal, \& } \\
\begin{array}{l}\text { Ovtcharo- } \\
\text { va, 2013) }\end{array}\end{array}$ & $\begin{array}{l}\text { Product Life- } \\
\text { cycle Manage- } \\
\text { ment (PLM) }\end{array}$ & $\begin{array}{l}\text { Scientific fa- } \\
\text { cilities }\end{array}$ & Ad-Hoc & $\begin{array}{l}\text { CMMI, International Atomic Energy Agency } \\
\text { (standards), SPICE-BOOTSTRAP, Project } \\
\text { Management Maturity Model, Systems Engi- } \\
\text { neering Capability Model, ISO 9000-3, ISO/ } \\
\text { IEC 12207, ISO 9001, ISO 10007: 2003, EIA- } \\
\text { 649-B, MIL-STD-3046 }\end{array}$ & \\
\hline
\end{tabular}


Table 13: Summary of Research Results

CM

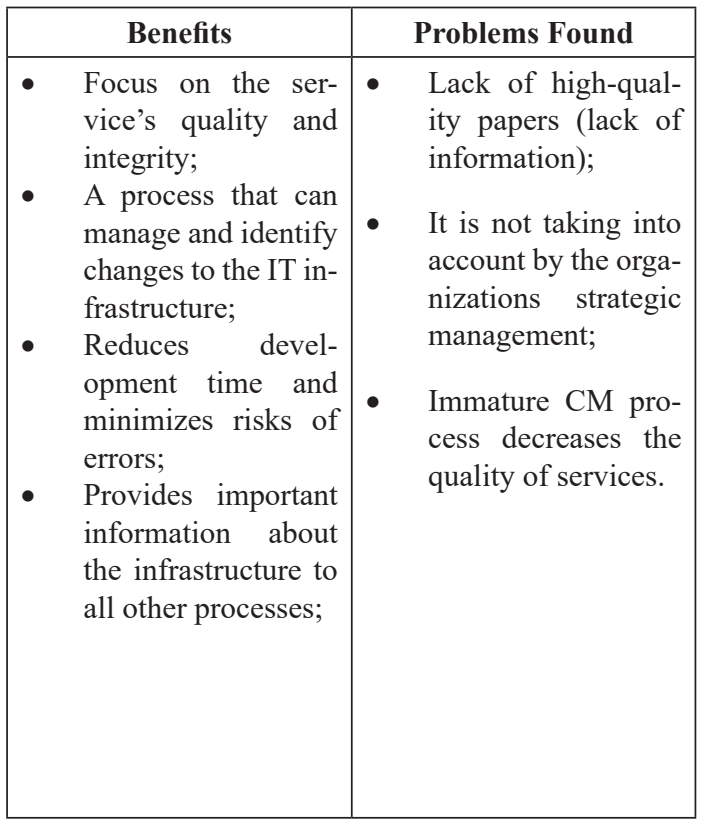

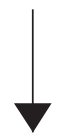

MM

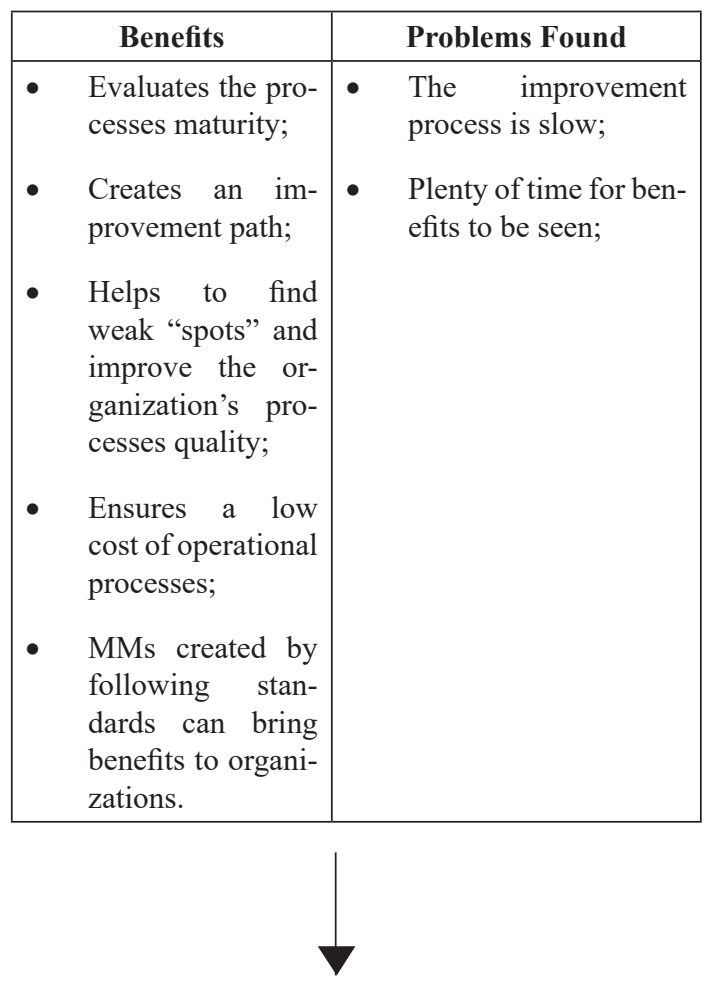

Benefits of the conjunction of both domains

- Creates an improvement path to the CM process;

- Evaluates the as-is state of the CM process;

- Better knowledge and management of the CM process, which brings a better quality of management and efficiency of the IT infrastructure;

- Possibility of mitigating the problems and errors of the bad CM process execution.

\section{Conclusion}

Two MMs that address the CM practices were found, however, none of those MMs focus on IT Services. This research can represent an opportunity for the development of MM for the CM process.

\section{Conclusion}

Due to the constant pressures of the market and the environment, such as the reduced costs of operations, but with the requirement of maintaining the same or better quality, organizations need to constantly upgrade themselves by having mature processes, and MMs can serve as an excellent tool to improve organizations' processes. With the Systematic Literature Review methodology and Concept Centric method, it was possible to explain the $\mathrm{CM}$ and MMs concepts and their main characteristics and benefits, such as their problems and difficulties.

On the CM domain research, the number of result articles was just 30 , and some of them are from the 1990s. This demonstrates that, although it is proven that the CM process could be essential for an organization, research done by the scientific community in higher-ranked journals/conferences in this domain and CM recognition is much more underdeveloped than it should be. Different from CM, on MMs research, many articles about the creation of new MMs and their importance in a broad domain variety were found, which reveals the substantial MM importance for an organization. 
Still, a brief search of MMs for CM was made and two articles were found. However, any of these MMs address the IT Services domain, which underscores the fact that the development of a MM for the CM would be a feasible and helpful tool for IT Services providers.

Also, this investigation, by comparing the benefits and the utility that a CM would have in the management of an IT organization, concluded that a MM specific for $\mathrm{CM}$ would be an essential quality tool for an organization, such as the utilization of frameworks for the development of this kind of utensil.

These reviews will help new researchers to have a knowledge basis to start new research in these domains and can be a support base for the creation of a MM for the $\mathrm{CM}$ process.

\section{Literature}

Achi, A., Salinesi, C., Viscusi, G., Krogstie, J., Mouratidis, H., \& Su, J. (2016). Information Systems for Innovation: A Comparative Analysis of Maturity Models' Characteristics. In Conference on Advanced Information Systems Engineering (Vol. 249, pp. 78-90). Cham: Springer International Publishing. https://doi.org/10.1007/978-3-319-39564-7_8

Aguiar, J., Pereira, R., Vasconcelos, J.B. \& Bianchi, I. (2018).. An Overlapless Incident Management Maturity Model for Multi-Framework Assessment (ITIL, COBIT, CMMI-SVC). Interdisciplinary Journal of Information, Knowledge, and Management, 13, 137163. https://doi.org/http://dx.doi.org/10.28945/4083

Aleksic, A., Atanasijevic, S., Radišić, M., \& Eric, M. (2010). Configuration Management and ICT: A Case Study of Improving Quality of Processes by System Virtualization. In International Conference on Information Quality.

Ali, U., \& Kidd, C. (2013). Critical success factors for configuration management implementation. Industrial Management and Data Systems, 113(2), 251-264. https://doi.org/10.1108/02635571311303569

Ali, U., \& Kidd, C. (2014). Barriers to effective configuration management application in a project context: An empirical investigation. International Journal of Project Management, 32(3), 508-518.

https://doi.org/10.1016/j.ijproman.2013.06.005

Ali, U., \& Kidd, C. (2015). Configuration Management maturation: An empirical investigation. Proceedings of the Institution of Mechanical Engineers, Part B: Journal of Engineering Manufacture, 229(2), 321-327. https://doi.org/10.1177/0954405414527958

Antunes, P., Carreira, P., \& Silva, M. M. da. (2014). Towards an energy management maturity model. Energy Policy, 73, 803-814. https://doi.org/10.1016/j.enpol.2014.06.011

Asif, M. (2016). Understanding a Co-Evolution Model of Business and IT for Dynamic Business Process Re- quirements. International Journal of Advanced Computer Science and Applications, 7(2), 348-352. https://doi.org/10.14569/IJACSA.2016.070248

Baiôco, G., Costa, A. C. M., Calvi, C. Z., \& Garcia, A. S. (2009). IT service management and governance: Modeling an ITSM configuration process: A foundational ontology approach. In 2009 IFIP/IEEE International Symposium on Integrated Network Management-Workshops, IM 2009 (pp. 24-33).

https://doi.org/10.1109/INMW.2009.5195930

Baiôco, G., \& Garcia, A. S. (2010). Implementation and application of a well-founded configuration management ontology. In 2010 IEEE/IFIP Network Operations and Management Symposium Workshops, NOMS 2010 (pp. 80-87). Osaka: IEEE.

https://doi.org/10.1109/NOMSW.2010.5486596

Becker, J., Knackstedt, R., \& Pöppelbuß, J. (2009). Developing Maturity Models for IT Management - A Procedure Model and its Application. Wirtschaftsinformatik, $1,213-222$.

https://doi.org/10.1007/s12599-009-0044-5

Bezerra, T. R., Moura, A., \& Lima, A. S. (2014). A system dynamics model to support strategic decision making on IT outsourcing: A case study at a state revenue agency in Brazil. In IEEE Network Operations and Management Symposium (NOMS) (pp. 1-4). https://doi.org/10.1109/NOMS.2014.6838369

Brookes, N., Butler, M., Dey, P., Clark, R., \& Beverly, D. (2014). The use of maturity models in improving project management performance: An empirical investigation. International Journal of Managing Projects in Business, 7(2), 231-246.

https://doi.org/10.1108/IJMPB-03-2013-0007

Brooks, P., El-Gayar, O., \& Sarnikar, S. (2015). A framework for developing a domain specific business intelligence maturity model: Application to healthcare. International Journal of Information Management, 35(3), 337-345.

https://doi.org/10.1016/j.ijinfomgt.2015.01.011

Buchmann, T., Dotor, A., \& Westfechtel, B. (2013). MOD2-SCM: A model-driven product line for software configuration management systems. Information and Software Technology, 55(3), 630-650. https://doi. org/10.1016/j.infsof.2012.07.010

Burgess, T. F., McKee, D., \& Kidd, C. (2005). Configuration management in the aerospace industry: A review of industry practice. International Journal of Operations and Production Management, 25(3), 290-301. https://doi.org/10.1108/01443570510581880

Caffery, F., \& Coleman, G. (2007). Developing a configuration management capability model for the medical device industry. International Journal of Information Systems and Change Management, 2(2), 139. https://doi.org/10.1504/IJISCM.2007.015117

Calhau, R. F., \& de Almeida Falbo, R. (2012). A Configuration Management task ontology for semantic integration. In Proceedings of the 27th Annual ACM Symposium on Applied Computing - SAC '12 (p. 348). ACM. 
https://doi.org/10.1145/2245276.2245344

Carvalho, J., Rocha, Á., Vasconcelos, J., \& Abreu, A. (2018). A health data analytics maturity model for hospitals information systems. International Journal of Information Management.

https://doi.org/10.1016/j.ijinfomgt.2018.07.001

Carvalho, J. V., Rocha, Á., Abreu, A., Mejia, J., Muñoz, M., San Feliu, T., \& Peña, A. (2017). HISMM - Hospital Information System Maturity Model: A Synthesis. In J. Mejia, M. Muñoz, Á. Rocha, T. San Feliu, \& A. Peña (Eds.), Conference on Software Process Improvement (Vol. 537, pp. 189-200). Cham: Springer International Publishing.

https://doi.org/10.1007/978-3-319-48523-2 18

Choi, I., \& Bae, S. (2001). An architecture for active product configuration management in industrial virtual enterprises. International Journal of Advanced Manufacturing Technology, 18(2), 133-139.

https://doi.org/10.1007/s001700170084

Cleven, A. K., Winter, R., Wortmann, F., \& Mettler, T. (2014). Process management in hospitals: an empirically grounded maturity model. Business Research, 7(2), 191-216.

https://doi.org/10.1007/s40685-014-0012-x

Conradi, R., \& Westfechtel, B. (1998). Version models for software configuration management. ACM Computing Surveys, 30(2), 232-282.

https://doi.org/10.1145/280277.280280

Curley, M., van der Aalst, W., Mylopoulos, J., Sadeh, N. M., Shaw, M. J., Szyperski, C., ... Cardoso, J. (2008). Introducing an IT Capability Maturity Framework. In W. van der Aalst, J. Mylopoulos, N. M. Sadeh, M. J. Shaw, C. Szyperski, J. Filipe, ... J. Cardoso (Eds.), International Conference on Enterprise Information Systems (Vol. 12, pp. 63-78). Berlin, Heidelberg: Springer Berlin Heidelberg.

https://doi.org/10.1007/978-3-540-88710-2 6

Curry, E., Conway, G., Donnellan, B., Sheridan, C., Ellis, K., Gelenbe, E., \& Lent, R. (2013). Measuring Energy Efficiency Practices in Mature Data Center: A Maturity Model Approach. In International Symposium on Computer and Information Sciences (pp. 51-61). London: Springer London.

https://doi.org/10.1007/978-1-4471-4594-3_6

Desharnais, J.-M., \& April, A. (2010). Software Maintenance Productivity and Maturity. In Proceedings of the 11th International Conference on Product Focused Software (pp. 121-125). New York, NY, USA: ACM. https://doi.org/10.1145/1961258.1961289

Ertürk, A., \& Vurgun, L. (2015). Retention of IT professionals: Examining the influence of empowerment, social exchange, and trust. Journal of Business Research, 68(1), 34-46.

https://doi.org/10.1016/j.jbusres.2014.05.010

Fahmy, S., Deraman, A., \& Yahaya, J. H. (2018). The Role of Human in Software Configuration Management. In International Computer Software and Applications Conference (pp. 56-60). \{ACM $\}$ Press. https://doi.org/10.1145/3185089.3185117

Finnerty, N., Sterling, R., Coakley, D., \& Keane, M. M. (2017). An energy management maturity model for multi-site industrial organisations with a global presence. Journal of Cleaner Production, 167, 1232-1250. https://doi.org/10.1016/j.jclepro.2017.07.192

Fowler, A. (1996). Case experience of implementing configuration management in a UK shipbuilding organization. International Journal of Project Management, 14(4), 221-230.

https://doi.org/10.1016/0263-7863(95)00094-1

Frick, N., Küttner, T. F., \& Schubert, P. (2013). Assessment Methodology for a Maturity Model for Interorganizational Systems - The Search for an Assessment Procedure. In Hawaii International Conference on System Sciences (pp. 274-283).

https://doi.org/10.1109/HICSS.2013.106

Giese, H., Seibel, A., \& Vogel, T. (2010). A Model-Driven Configuration Management System for Advanced IT Service Management. In ACM/IEEE International Conference on Model-Driven Engineering Languages and Systems (p. 11).

Haes, B. S. De, \& Grembergen, W. Van. (2004). IT Governance and Its Mechanisms. Information Systems Audit and Control Association.

Hamel, F., Herz, T. P., Uebernickel, F., \& Brenner, W. (2013). IT Evaluation in Business Groups: A Maturity Model. In ACM (Ed.), ACM Symposium on Applied Computing (pp. 1410-1417). New York, NY, USA: ACM. https://doi.org/10.1145/2480362.2480627

Hammers, S., Kormann, G., Moser, T., Reiner, M., Stolfa, J., Stolfa, S., ... Messnarz, R. (2017). A Conceptual Mixed Realities (AR/VR) Capability Maturity Model - With Special Emphasis on Implementation. In European Conference on Software Process Improvement (Vol. 748, pp. 372-377). Cham: Springer International Publishing.

https://doi.org/10.1007/978-3-319-64218-5_31

Hashmi, S. I., Lane, S., Karastoyanova, D., \& Richardson, I. (2010). A CMMI Based Configuration Management Framework to Manage the Quality of Service Based Applications. In European conference on Software Process Improvement (p. 10).

Hauck, J. C. R., \& Wangenheim, C. G. v. (2011). A Method for Software Process Capability / Maturity Models Customization to Specific Domains. In Brazilian Symposium on Software Engineering (pp. 293-302). https://doi.org/10.1109/SBES.2011.23

Humphrey, W. S. (1988). Characterizing the software process: a maturity framework. IEEE Software, 5(2), 73-79. https://doi.org/10.1109/52.2014

Hüner, K. M., Ofner, M., \& Otto, B. (2009). Towards a Maturity Model for Corporate Data Quality Management. In ACM Symposium on Applied Computing (pp. 231-238). New York, NY, USA: ACM. https://doi.org/10.1145/1529282.1529334

Introna, V., Cesarotti, V., Benedetti, M., Biagiotti, S., \& Rotunno, R. (2014). Energy Management Maturity 
Model: an organizational tool to foster the continuous reduction of energy consumption in companies. Journal of Cleaner Production, 83, 108-117. https://doi.org/10.1016/j.jclepro.2014.07.001

Jia, G., Ni, X., Chen, Z., Hong, B., Chen, Y., Yang, F., \& Lin, C. (2013). Measuring the maturity of risk management in large-scale construction projects. Automation in Construction, 34, 56-66.

https://doi.org/10.1016/j.autcon.2012.10.015

Jiang, J. J., Klein, G., Hwang, H.-G., Huang, J., \& Hung, S.Y. (2004). An exploration of the relationship between software development process maturity and project performance. Information \& Management, 41(3), 279288. https://doi.org/10.1016/S0378-7206(03)00052-1

Johnson, M. W., Hately, A., Miller, B. A., \& Orr, R. (2007). Evolving standards for IT service management. IBM Systems Journal, 46(3), 583-597. https://doi.org/10.1147/sj.463.0583

Karni, R., Kaner, M., Shimomura, Y., \& Kimita, K. (2013). A Review of Maturity Models and their Application to PSS: Towards a PSS Maturity Model. In S. B. Heidelberg (Ed.), CIRP (pp. 393-398). Berlin, Heidelberg: Springer Berlin Heidelberg. https://doi.org/10.1007/978-3-642-32847-3_66

Kayaga, S., Mugabi, J., \& Kingdom, W. (2013). Evaluating the institutional sustainability of an urban water utility: A conceptual framework and research directions. Utilities Policy, 27, 15-27. https://doi.org/10.1016/j.jup.2013.08.001

Kitchenham, B. (2004). Procedures for Performing Systematic Reviews. http://dx.doi.org/10.1.1.122.3308

Knahl, M. H., Bayro-Corrochano, E., \& Hancock, E. (2013). Application of IT Management Frameworks in Higher Education Institutions. In Conference on $A d-$ vanced Information Systems Engineering (Vol. 8827, pp. 124-133). Cham: Springer International Publishing. https://doi.org/10.1007/978-3-642-38490-5_10

Kwak, Y., Sadatsafavi, H., Walewski, J., \& Williams, N. L. (2015). Evolution of project based organization: A case study. International Journal of Project Management, 33(8), 1652-1664.

https://doi.org/10.1016/j.ijproman.2015.05.004

Lã, A. (2011). A Maturity Model for Analyzing Strategic IT Management from a service perspective. In AMCIS (p. 12).

Lahrmann, G., Marx, F., Kanade, T., Kittler, J., Kleinberg, J. M., Mattern, F., ... Aier, S. (2010). Systematization of Maturity Model Extensions. In International Conference on Design Science Research in Information Systems (Vol. 6105, pp. 522-525). Berlin, Heidelberg: Springer Berlin Heidelberg. http://dx.doi.org/10.1007/978-3-642-13335-0 36

Lahtela, A., \& Jantti, M. (2010). Improving IT Service Management Processes: A Case Study on IT Service Support. In A. Riel, R. O'Connor, S. Tichkiewitch, \& R. Messnarz (Eds.), Systems, Software and Services Process Improvement (Vol. 99, pp. 95-106). Berlin, Heidelberg: Springer Berlin Heidelberg. https://doi.org/10.1007/978-3-642-15666-3_9

Levstek, A., Hovelja, T., \& Pucihar, A. (2018). IT Governance Mechanisms and Contingency Factors: Towards an Adaptive IT Governance Model. Organizacija, 51(4), 286-310. https://doi.org/10.2478/orga-2018-0024

M. Fairchild, A. (2004). Information technology outsourcing (ITO) governance: an examination of the outsourcing management maturity model. In Annual Hawaii International Conference on System Sciences, 2004. Proceedings of the (p. 8 pp.-).

https://doi.org/10.1109/HICSS.2004.1265565

Madduri, H., Shi, S. S. B., Baker, R., Ayachitula, N., Shwartz, L., Surendra, M., ... Patel, S. (2007). A configuration management database architecture in support of IBM Service Management. IBM Systems Journal, 46(3), 441-457. https://doi.org/10.1147/sj.463.0441

Mallett, R., Hagen-Zanker, J., Slater, R., \& Duvendack, M. (2012). The benefits and challenges of using systematic reviews in international development research. Journal of Development Effectiveness, 4(3), 445-455. http://dx.doi.org/10.1080/19439342.2012.711342

Marrone, M., \& Kolbe, L. M. (2010). ITIL and the Creation of Benefits: An Empirical Study on Benefits, Challenges and Processes. In European Conference on Information Systems (p. 15).

Marrone, M., \& Kolbe, L. M. (2011). Uncovering ITIL claims: IT executives' perception on benefits and Business-IT alignment. Information Systems and E-Business Management, 9(3), 363-380. https://doi.org/10.1007/s10257-010-0131-7

Mayer, J., \& Fagundes, L. L. (2009). A model to assess the maturity level of the Risk Management process in information security. In International Symposium on Integrated Network Management-Workshops (pp. 61-70). https://doi.org/10.1109/INMW.2009.5195935

Mettler, T., \& Rohner, P. (2009). Situational Maturity Models As Instrumental Artifacts for Organizational Design. In Proceedings of the 4th International Conference on Design Science Research in Information Systems and Technology (p. 22:1-22:9). New York, NY, USA: ACM. https://doi.org/10.1145/1555619.1555649

Na-Lampang, N., \& Vatanawood, W. (2016). Development of an ontology-based configuration management system. In 2016 8th International Conference on Electronics, Computers and Artificial Intelligence (ECAI) (pp. 1-6). https://doi.org/10.1109/ECAI.2016.7861164

Niknam, M., Bonnal, P., \& Ovtcharova, J. (2013). Configuration Management Maturity in Scientific Facilities. International Journal of Advanced Robotic Systems, 10(12), 404. https://doi.org/10.5772/56853

Nord, F., Dorbecker, R., \& Bohmann, T. (2016). Structure, Content and Use of IT Service Catalogs -- Empirical Analysis and Development of a Maturity Model. In IEEE (Ed.), Hawaii International Conference on System Sciences (HICSS) (pp. 1642-1651). Koloa, HI, USA: IEEE. https://doi.org/10.1109/HICSS.2016.207

Okoli, C., \& Schabram, K. (2010). Working Papers on In- 
formation Systems A Guide to Conducting a Systematic Literature Review of Information Systems Research. Sprouts, 10.

Pã, J. (2011). What Mkaes a Useful Maturity Model? A Framework of General Design Principles for Maturity Models and its Demonstration in Business Process Management. In European Conference on Information Systems (p. 13).

Pala Er, N., \& Erbaş, C. (2010). Aligning Software Configuration Management with Governance Structures. In International Conference on Software Engineering (pp. 1-8). ACM. https://doi.org/10.1145/1808981.1808982

Pantoni, R. P., Mossin, E. A., Donaires, O. S., \& Brandão, D. (2007). Configuration management for fieldbus automation systems. In IEEE International Symposium on Industrial Electronics (pp. 1844-1848). Vigo, Spain: IEEE. https://doi.org/10.1109/ISIE.2007.4374886

Park, E. J., Kim, H. K., \& Lee, R. Y. (2007). Frameworks of integration repository for software process improvement using SOA. In Proceedings - 6th IEEE/ACIS International Conference on Computer and Information Science, ICIS 2007; 1st IEEE/ACIS International Workshop on e-Activity, IWEA 2007 (pp. 200-205). https://doi.org/10.1109/ICIS.2007.102

Patas, J., Pöppelbuß, J., \& Goeken, M. (2013). Cherry picking with meta-models: A systematic approach for the organization-specific configuration of maturity models. In J. vom Brocke, R. Hekkala, S. Ram, \& M. Rossi (Eds.), Lecture Notes in Computer Science (including subseries Lecture Notes in Artificial Intelligence and Lecture Notes in Bioinformatics) (Vol. 7939 LNCS, pp. 353-368). Berlin, Heidelberg: Springer Berlin Heidelberg. https://doi.org/10.1007/978-3-642-38827-9 24

Pereira, R., \& Mira, M. (2010). A Maturity Model for Implementing ITIL v3. In IEEE (Ed.), 2010 6th World Congress on Services (pp. 399-406). Miami, FL, USA. https://doi.org/10.1109/SERVICES.2010.80

Picard, M., Renault, A., Barafort, B., O'Connor, R. V., Umay Akkaya, M., Kemaneci, K., ... Messnarz, R. (2015). A Maturity Model for ISO/IEC 20000-1 Based on the TIPA for ITIL Process Capability Assessment Model. In R. V O'Connor, M. Umay Akkaya, K. Kemaneci, M. Yilmaz, A. Poth, \& R. Messnarz (Eds.), European Conference on Software Process Improvement (Vol. 543, pp. 168-179). Cham: Springer International Publishing.

https://doi.org/10.1007/978-3-319-24647-5_14

Proença, D. (2016). Methods and Techniques for Maturity Assessment. In Iberian Conference on Information Systems and Technologies (CISTI).

Proença, D., \& Borbinha, J. (2018). Using Enterprise Architecture Model Analysis and Description Logics for Maturity Assessment. In Proceedings of the 33rd Annual ACM Symposium on Applied Computing (pp. 102-109). New York, NY, USA: ACM.

https://doi.org/10.1145/3167132.3167140

Proença, D., Borbinha, J., Abramowicz, W., \& Paschke,
A. (2018). Information Security Management Systems - A Maturity Model Based on ISO/IEC 27001. In International Conference on Business Information Systems (Vol. 320, pp. 102-114). Cham: Springer International Publishing.

https://doi.org/10.1007/978-3-319-93931-5_8

Proença, D., Vieira, R., Antunes, G., da Silva, M. M., Borbinha, J., Becker, C., \& Kulovits, H. (2013). Evaluating a Process for Developing a Capability Maturity Model. In Proceedings of the 28th Annual ACM Symposium on Applied Computing (pp. 1474-1475). New York, NY, USA: ACM.

https://doi.org/10.1145/2480362.2480637

Proença, D., Vieira, R., Borbinha, J., Kamps, J., Tsakonas, G., Manolopoulos, Y., ... Karydis, L. (2017). Information Governance Maturity Model Final Development Iteration. In Conference on Theory and Practice of Digital Libraries (Vol. 10450, pp. 128-139). Cham: Springer International Publishing.

https://doi.org/10.1007/978-3-319-67008-9 11

Rao, V., \& Jamieson, R. (2003). An Approach to Implementing Maturity Models in IT Security. In ACIS (pp. $1-11)$.

Reis, L., Kipper, L., Velásquez, F. D. G., Hofmann, N., Frozza, R., Ocampo, S. A., \& Hernandez, C. A. (2018). A model for Lean and Green integration and monitoring for the coffee sector. Computers and Electronics in Agriculture, 150, 62-73.

https://doi.org/10.1016/j.compag.2018.03.034

Reis, T. L., Mathias, M. A. S., \& de Oliveira, O. J. (2017). Maturity models: identifying the state-of-the-art and the scientific gaps from a bibliometric study. Scientometrics, 110(2), 643-672.

https://doi.org/10.1007/s11192-016-2182-0

Röglinger, M., Pöppelbuß, J., \& Becker, J. (2012). Maturity models in business process management. Business Process Management Journal, 18(2), 328-346. https://doi.org/10.1108/14637151211225225

Röglinger, M., Schwindenhammer, L., Stelzl, K., Weske, M., Montali, M., Weber, I., \& vom Brocke, J. (2018). How to Put Organizational Ambidexterity into Practice - Towards a Maturity Model. In International Conference on Business Process Management (Vol. 329, pp. 194-210). Cham: Springer International Publishing. https://doi.org/10.1007/978-3-319-98651-7_12

Salman, R., Daim, T., Raffo, D., \& Dabic, M. (2018). Exploring capability maturity models and relevant practices as solutions addressing information technology service offshoring project issues. International Journal of Management Science and Engineering Management, 13(3), 147-157.

https://doi.org/10.1080/17509653.2017.1381052

Schäffer, T., Leyh, C., Bley, K., \& Schimmele, M. (2018). Towards an Open Ecosystem for Maturity Models in the Digital Era: The Example of the Data Quality Management Perspective. In AMCIS (p. 11).

Serenko, A., Bontis, N., \& Hull, E. (2016). An application of the knowledge management maturity model: 
the case of credit unions. Knowledge Management Research \& Practice, 14(3), 338-352.

https://doi.org/10.1057/kmrp.2014.37

Shah, S. N. M., Khalid, M., Mahmood, A. K. Bin, Haron, N., \& Javed, M. Y. (2012). Implementation of software process improvement in Pakistan: An empirical study. In 2012 International Conference on Computer and Information Science, ICCIS 2012 - A Conference of World Engineering, Science and Technology Congress, ESTCON 2012 - Conference Proceedings (Vol. 2, pp. 1006-1013).

https://doi.org/10.1109/ICCISci.2012.6297173

Tellioglu, H. (1996). Configuration Management in Collaborative Writing. In Americas Conference on Information Systems (p. 4).

Vanbrabant, B., \& Joosen, W. (2013). A framework for integrated configuration management tools. In 2013 Ifip/ Ieee International Symposium on Integrated Network Management (pp. 534-540). Retrieved from https://lirias.kuleuven.be/handle/123456789/398467

Vezzetti, E., Violante, M., \& Marcolin, F. (2014). A benchmarking framework for product lifecycle management (PLM) maturity models. The International Journal of Advanced Manufacturing Technology, 71(5-8), 899918. https://doi.org/10.1007/s00170-013-5529-1

Wandel, A. P., Jokic, M. D., \& Kist, A. A. (2013). Caring and sharing computer files with configuration management. In AAEE - Annual Conference of Australasian Association for Engineering Education (p. 9).

Wang, L., Xue, X., Wy, H., \& Candidate, P. (2016). A Framework for Developing an Engineering Management Theory Maturity Model. In International Conference on Construction and Real Estate Management ( $\mathrm{p}$. 8).

Ward, C., Aggarwal, V., Buco, M., Olsson, E., \& Weinberger, S. (2007). Integrated change and configuration management. IBM Systems Journal, 46(3), 459-478. https://doi.org/10.1147/sj.463.0459

Webster, J., \& T. Watson, R. (2002). Analyzing the Past to Prepare for the Future: Writing a Literature Review. MIS Quarterly, 26(2), 256-261.

https://doi.org/http://dx.doi.org/10.1.1.104.6570

Wendler, R. (2012). The maturity of maturity model research: A systematic mapping study. Information and Software Technology, 54(12), 1317-1339. https://doi.org/10.1016/j.infsof.2012.07.007

Whyte, J., Stasis, A., \& Lindkvist, C. (2016). Managing change in the delivery of complex projects: Configuration management, asset information and "big data." International Journal of Project Management, 34(2), 339-351. https://doi.org/10.1016/j.ijproman.2015.02.006

Yang, B. (2010). Knowledge-enhanced change audit for configuration management. In Proceedings of the 2010 IEEE/IFIP Network Operations and Management Symposium, NOMS 2010 (pp. 898-901). Osaka, Japan: IEEE.

https://doi.org/10.1109/NOMS.2010.548834
João Serrano has a degree in Computer Science Engineering at Instituto Politécnico de Leiria (ESTG). He has a Master Degree in Computer Science and Management at ISCTE. He is currently attending a $\mathrm{PhD}$ in Computer Science and Technology at ISCTE. In his academic career has explored domains such as Management, Software Development and Systems Management.

Ruben Pereira, is an Assistant Professor at ISCTE. $\mathrm{He}$ has a PhD in Information Systems at Instituto Superior Técnico where he also graduated as a Master in Computer Engineering and Computer Science. He has been a consultant in several industries, such as services, banking, telecommunications, and E-commerce, among others. He is the author of several scientific papers in the domain of Information Technology Services Management and Information Technology Governance, covering the most adopted IT Frameworks like ITIL and COBIT. Its domains of scientific interest extend to: Information Technology Risk Management, Business Process Management, continuous improvement and innovation, process optimization, Digital Transformation, among others. 